\title{
Characterization of Soybean Cultivars Genetically Improved for Human Consumption
}

\author{
Aline Andressa Rigo, Alice Maria Dahmer, Clarice Steffens, and Juliana Steffens \\ Department of Food Engineering, URI Erechim, Brazil \\ Email: aline.andressa@ hotmail.com, amdahmer@uol.com.br, \{claristeffens, julianasteffens\}@yahoo.com.br \\ Mercedes Concórdia Carrão-Panizzi \\ Empresa Brasileira de Pesquisa Agropecuária (Embrapa) - Passo Fundo, RS, Brazil \\ Email: mercedes.panizzi@embrapa.br
}

\begin{abstract}
Soybean (Glycine max (L.) Merrill) is a crop of world economic importance. Conventional soybean cultivars, in general are for the oil extraction industries and its subproduct for animal feeding. However, there are some cultivars genetically modified, that present characteristics adapted for different utilizations, including human food. The objective of this work was to evaluate, three soybean cultivars, Vmax (conventional), and BR 257 and 267 (human food uses). Chemical composition was evaluated in grains with tegument (WT) and without tegument (WIT) heat treated (HT) and non-heat treated (NHT). For characterization, it was observed: humidity, proteins, lipids, minerals, nitrogen solubility index (NSI), protein dispersability index (PDI), isoflavones, Kunitz trypsin inhibitor and lipoxygenases. The heat treatment promoted reduction of the protein solubility, reduction of glucosidic and malonyl isoflavones, and of Kunitz trypsin inhibitor, in grains WIT. Lipoxygenases were also inactivated in BRS 267 and Vmax cultivars. Potassium was the mineral present in higher amount in all cultivars. BRS 267 cultivar showed the highest content of protein, but the lowest content of isoflavones. Vmax cultivar showed the highest content of lipids and isoflavones. Heat treatments, although decreasing protein solubility, are necessary for conventional soybeans to improve flavor and to reduce anti nutritional factors. Depending on the objective of soybean utilization, different cultivars and treatments should be applied. Genetic breeding to obtain soybean cultivars with special characters is important to process high quality soybean products.
\end{abstract}

Index Terms - soybean grains, isoflavones, Kunitz trypsin inhibitor, protein solubility, lipoxygenases, heat treatment

\section{INTRODUCTION}

Soybean is one of the protein source most used in the world. However, its organoleptic characteristics are not well accepted for human consumption [1]. Therefore, the development of soybean cultivars more suitable for food utilization is important to attend the demand of the niche market that requires special cultivars with better quality characteristics [2].

Considering the need for soybean products with better flavor and high nutritive value, Brazilian Agriculture

Manuscript received December 15, 2014; revised March 30, 2015.
Research Corporation (EMBRAPA) - National Soybean Research Center developed, throughout its genetic breeding program, some soybean cultivars, with special characteristics for different utilizations [3], [4].

The soybean BRS 267 cultivar presents large seed size, which when harvested at the growth stage R6 (completed developed, immature green grains), can be used as "Edamame", or for preparation of tofu when its grains are matured [4]. This cultivar presents high content of protein, oleic acid, isoflavone aglycones, sugars, and the amino acids, glutamic e alanine, that are characteristics that improve nutritional value and flavor of soy foods [5].

The BRS 257 cultivar, does not present the enzymes lipoxygenases, which are responsible for the development the rancid and the beany flavor, it has high yield potential and it is indicated for flour and soymilk processing. Since the lipoxygenases are not present in the grain of the BRS 257 , heat treatment to inactive the enzymes is not necessary [4].

The soybean protein is the only vegetal protein that contains all the essential amino acids that support growth and maintenance of an organism, according to the World Health Organization (WHO [6]. Solubility of the soybean proteins is also an important property, because it defines the adequate utilization of in food processing. Functional properties, as foaming, emulsification and gelification, are affected by the protein solubility [7]-[9].

Soybean presents other chemical compounds as isoflavones that can interfere in the physiology of the cells, as in the proliferation, growth and maturity, acting as important regulators to maintain health. These compounds, as genistein and daidzein, have antioxidant properties, protecting cells of the deleterious effects of the free radicals that promote ageing [10].

Therefore, soybean presents antinutritional factors that limit its utilization and acceptability [11]. Among them, the Kunitz trypsin inhibitor is the most studied, because it affects the digestibility of soybean proteins. This inhibitor acts in the gastrointestinal tract reducing availability of the amino acids, limiting the nutritional value of this legume [12], [13].

Therefore, the objective of this study was to determine chemical compounds related to quality and protein solubility in grains with and without tegument submitted 
to heat treatment of three soybean cultivars Vmax (conventional), and BR 257, 267 (human consumption).

\section{MATERIAL AND METHODS}

\section{A. Material}

The grains of the soybean Vmax, BRS 257 and BRS 267 cultivars were received from Embrapa (soybean season 2012/2013), cultivated in Passo Fundo - Rio Grande do Sul State, Brazil (Latitude $28^{\circ} 15^{\prime} 40^{\prime \prime}$ ). For the evaluation, grains were divided into two types of samples: with tegument (WT) and without tegument (WIT) which were mechanical dehulled ("Maqsoy ${ }^{\circledR}$ " machine).

BRS 267 and Vmax cultivars contain the enzyme lipoxygenases (LOX) in their composition and because of that according to Ref. [14], grain samples of these cultivars were submitted to thermal treatment (water bath at $98^{\circ} \mathrm{C}$ for $5 \mathrm{~min}$ ). After heat treatment, grains were dried at $40^{\circ} \mathrm{C}$ in air circulating oven (Marconi®), as recommended by Ref. [15] for $24 \mathrm{~h}$ to constant weight. The cultivar BRS 257, which is null for lipoxygenases [16], was not submitted to the heat treatment.

\section{B. Characterization}

Moisture was determined by the gravimetric method, in a drying chamber (Nova Ética) at $105^{\circ} \mathrm{C}$ for about $4 \mathrm{~h}$ to constant weight. The values of the grain moisture were standardize in $8.45 \%$ (dried extract of 91.55), for analyses of proteins, lipids and ashes. Proteins were determined by Kjeldahl method. Lipids were determined by the Soxhlet method, and ashes were obtained by gravimetric method, after calcination in a muffle oven (Quimis), at $550^{\circ} \mathrm{C}$ for $6 \mathrm{~h}$. All the analyses were performed according to the methods in Ref. [17] and results were expressed in g. $100 \mathrm{~g}^{-1}$ at dry basis.

Extraction of metals $\mathrm{P}, \mathrm{K}, \mathrm{Ca}, \mathrm{Mg}, \mathrm{Zn}, \mathrm{Mn}, \mathrm{Fe}$ and $\mathrm{Cu}$ was performed by the wet digestion method in microwave oven, followed by analytical determination in ICP-OES (Inductively Coupled Plasma - Atomic Emission Spectrometry) [18], [19]. Results were expressed in $\mathrm{g} \cdot \mathrm{Kg}^{-1}$ wet basis.

The NSI was determined according to the method described in Ref. [20]. A sample of $5 \mathrm{~g}$ was diluted in $200 \mathrm{~mL}$ of distilled water, and mixed at $120 \mathrm{rpm}$ for $2 \mathrm{~h}$. Flasks were put in an incubator bath (Nova Ética®) at $30^{\circ} \mathrm{C}$. After this period, the supernatant was centrifuged (centrifuge MPW® model $351 \mathrm{R}$ ), for $10 \mathrm{~min}$ at $1500 \mathrm{rpm}$, and the filtrate was separated for determination of soluble protein by the official method [17]. The result was expressed in percentage $(\%)$.

The PDI was determined according to the method described in Ref. [21]. Samples of $10 \mathrm{~g}$ were diluted in $250 \mathrm{~mL}$ distilled water, and mixed with a homogenizer (model IKA T18 Basic Ultra-Turrax), at 8500rpm for 10 min. The supernatant was centrifuged (centrifuge MPW® model $351 \mathrm{R}$ ) for $10 \mathrm{~min}$ at $2700 \mathrm{rpm}$, and the filtrate was separated for determination of disperse protein by the official method [17]. The results were expressed in percentage $(\%)$.
The isoflavone content of the soybean grains "in nature" (non heat treated-NHT) and heat treated (HT) was performed according to the methodology of Ref. [22], and the sample extraction were carried out according to Ref. [23]. The separation and quantification of isoflavone was performed by high performance liquid chromatography (HPLC), in a Waters liquid chromatograph, equipped with photodiode array detector, model PDA 996. Elution and separation of isoflavones was performed on an ODS C18 YMC-Pack ODS-AM reverse phase column, with particles of $5 \mu \mathrm{m}, 4.6 \mathrm{~mm}$ diameter and $250 \mathrm{~mm}$ length, by linear gradient system. The initial condition consisted of $20 \%$ eluent A (methanol acidified with $0.025 \%$ trifluoroacetic acid) and $80 \%$ eluent B (ultrapure water acidified with $0.025 \%$ trifluoroacetic acid), with constant inversion until achieve $90 \%$ of eluent $\mathrm{A}$ and $10 \%$ eluent B after $35 \mathrm{~min}$. For the column cleanup, it was applied $100 \%$ of eluent A for 5 min, followed by inversion to initial conditions and a 20 min column re-equilibration before the next injection. The total analysis time was $60 \mathrm{~min}$ per injection, and solvent flow was maintained in $1 \mathrm{~mL}$.min-1. HPLC grade reagents were used in all steps. The quantification was performed by external standard calibration curves, using Sigma brand standards with known concentrations. Results are presented in dry defatted basis.

The Kunitz trypsin inhibitor was determined by the methodology described in Ref. [24]. The method is based on the level of inibition of the trypsin and in the hydrolyze of the substrate benzoil-DL-arginine-4nitroanilide hydrochloride (BAPA). The results were expressed in $\mathrm{mg}$ of trypsin inhibitor (TI). $100 \mathrm{~g}^{-1}$ of dry mass.

Determination of presence of the lipoxygenase isoenzymes was made by colorimetric test according to Ref. [25], which is based on the bleaching activity of the isoenzymes LOX on the linoleic acid substrate [26] and co-oxidation with methylene blue (LOX-1 e LOX-2) and $\beta$-carotene (LOX-3). The green color represents absence of the three isoenzymes.

All the experiments and chemical determinations were realized in triplicates, and the results submitted to the analysis of variance (ANOVA). Means were compared by Tukey test at $95 \%$ level of confidence by the Software Statistics 8.0.

\section{RESULTS AND DISCUSSION}

Results of ashes, lipids and proteins in the HT and NHT grains are presented in Table I.

Soybean grains did not present differences for ash contents between the same cultivar with WT and WIT tegument and between the treatments HT and NHT. The average content for ashes of all the samples was 4.89 g. $100 \mathrm{~g}^{-1}$. These results are similar to those obtained by Ref. [27], whose values were $5.11 \mathrm{~g} .100 \mathrm{~g}^{-1}$ for soybean grains before germination.

The higher content of lipids was observed in the

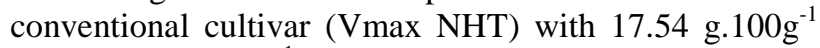
and $18.07 \mathrm{~g} .100 \mathrm{~g}^{-1}$ in the HT grains, WT and WIT respectively. The other cultivars were not different, 
presenting an average content of $14.63 \mathrm{~g} \cdot 100 \mathrm{~g}^{-1}$ for lipids. Ref. [28] evaluating the potential of different soybean cultivars for production of tofu, reported lipid content of
20.19 g. $100 \mathrm{~g}^{-1}$ and $18.55 \mathrm{~g} .100 \mathrm{~g}^{-1}$ in whole grains of the cultivars BRS 257 and BRS 267, respectively. These values were greater than those observed in this work.

TABle I. Content of Ashes, Lipids And Crude Protein in Soybean Grains Submitted to HeAt (HT) AND Non HeAt (NHT) Treatments

\begin{tabular}{|c|c|c|c|c|c|c|}
\hline \multirow{2}{*}{$\begin{array}{l}\text { Analysis } \\
\left(\mathrm{g.100g}^{-1}\right)\end{array}$} & & \multicolumn{5}{|c|}{ Cultivars } \\
\hline & & BRS 267 NHT* & BRS 267 HT* $^{*}$ & Vmax NHT* & Vmax HT* & BRS 257 NHT* \\
\hline \multirow{2}{*}{ Ashes } & WT & $5.05( \pm 0.41)^{\mathrm{aA}}$ & nd & $4.59( \pm 0.41)^{\mathrm{aA}}$ & nd & $5.05( \pm 0.10)^{\mathrm{aA}}$ \\
\hline & WIT & $5.03( \pm 0.20)^{\mathrm{aA}}$ & nd & $4.68( \pm 0.19)^{\mathrm{aA}}$ & nd & $4.97( \pm 0.03)^{\mathrm{aA}}$ \\
\hline \multirow{2}{*}{ Lipids } & WT & $14.19( \pm 061)^{\mathrm{bA}}$ & nd & $17.54( \pm 0.46)^{\mathrm{aA}}$ & nd & $14.42( \pm 1.22)^{\mathrm{bA}}$ \\
\hline & WIT & $15.06( \pm 0.58)^{\mathrm{bA}}$ & nd & $18.07( \pm 0.16)^{\mathrm{aA}}$ & nd & $14.86( \pm 1.14)^{\mathrm{bA}}$ \\
\hline \multirow{2}{*}{ Crude Protein } & WT & $38.77( \pm 0.35)^{\mathrm{bA}}$ & $42,14( \pm 0.17)^{\mathrm{aA}}$ & $34.79( \pm 0.47)^{\mathrm{dA}}$ & $37.06( \pm 0.05)^{\mathrm{cA}}$ & $36.62( \pm 0.48)^{\mathrm{cA}}$ \\
\hline & WIT & $40.30( \pm 0.49)^{\mathrm{bcB}}$ & $45,25( \pm 0.11)^{\mathrm{aB}}$ & $36.58( \pm 0.16)^{\mathrm{dB}}$ & $40.73( \pm 0.12)^{\mathrm{bB}}$ & $38.62( \pm 1.38)^{\mathrm{cA}}$ \\
\hline
\end{tabular}

*Means (three replicates), \pm Standard Deviation, same small/capital letters in the lines/columns indicate non significant differences at 5\% (Tukey test). Where: HT= grain with heat treatment; NHT = grain with non heat treatment; WT = with tegument; WIT= without tegument; nd = not determined

In the BRS 267 and Vmax cultivars submitted to heat the analyses for ashes and lipids were not determined, because the aim was only the LOX inactivation.

Analyzing grains NHT with WT and WIT, it was observed that BRS 267 cultivar was significantly different presenting high content of protein, $38.77 \mathrm{~g} .100 \mathrm{~g}^{-}$ 1 and 40.3 g. $100 \mathrm{~g}^{-1}$, respectively. Similar values were obtained by Ref. [5], who reported $44.49 \mathrm{~g} \cdot 100 \mathrm{~g}^{-1}$ of protein for the same cultivar.

Grains WIT presented higher protein content than the grains WT. This is because the greatest portion of protein (60-70\% of the total seed protein) be storage as protein bodies in the cotyledons [29].

With HT, BRS 267 and Vmax cultivars presented relatively higher content of proteins. In BRS 267 (HT), protein was $41.47 \mathrm{~g} .100 \mathrm{~g}^{-1}$ and $45.45 \mathrm{~g} .100 \mathrm{~g}^{-1}$ in grains (WT and WIT). These results corroborate with others studies. Ref. [5] also observed that with grains cooking there was an increased in protein content. Ref. [30], evaluating the effect of domestic processing of five common bean cultivars, observed that beans cooked in the soaking water presented more protein than the raw grains. Ref. [14], considered that heat treatment allow better conditions for extraction of proteins, increasing protein content of the products.

Results for mineral composition of soybean grains, in wet base, are presented in Table II and Table III. It was observed that for the micronutrients ( $\mathrm{Fe}, \mathrm{Cu}, \mathrm{Mn}$ and $\mathrm{Zn}$ ) did not present significant differences $(\mathrm{p}<0.05)$ for the
BRS 267 and Vmax cultivars, except of Mn for cultivar BRS 257 (Table II).

For macronutrients ( $\mathrm{Ca}, \mathrm{K}, \mathrm{Mg}$ and $\mathrm{P}$ ), BRS 257 cultivar presented the higher content for $\mathrm{Mg}$, in relation to the other cultivars. Among the cultivars, $\mathrm{K}$ was the mineral that presented the highest amount $\left(19.66 \mathrm{~g} . \mathrm{Kg}^{-1}\right)$, which was also observed by Ref. [31], [32].

In general, grains of the analyzed cultivars showed mineral content within the range observed in the literature [5]-[33]. For grains WT and WIT (Table III), only Fe presented a significant difference $(\mathrm{p}<0.05)$. Grains WIT presented $34.21 \%$ less of Fe than grains WT, which was also observed by Ref. [34].

In Table IV are presented results of the NSI and PDI, for the three soybean cultivars submitted to thermal treatments.

The PDI observed in grains (WT and WIT) of the three cultivars with NHT were not significant different, with an average of $82.55 \%$ and $87.45 \%$, respectively. However, BRS 267 and Vmax cultivars (NHT and HT), were significant different for the comparison of grains WT and WIT. Grains (WT) presented higher PDI, because of the seed integrity; presence of the tegument may protect protein.

Nitrogen Solubility Index was $68.01 \%$ higher in Vmax cultivar (NHT, WIT), significantly different of the others. The NSI of BRS 257 NHT and BRS 267 NHT, (WT and WIT) not presented differences, with average values of $62.94 \%$ and $62.10 \%$, respectively.

TABLE II. MineRAL COMPOSITION OF GRAINS OF SOYBEAN CULTIVARS

\begin{tabular}{|c|c|c|c|}
\hline \multirow{2}{*}{$\begin{array}{c}\text { Minerals } \\
\left(\mathbf{g . K g} \mathbf{K g}^{-1}\right)\end{array}$} & \multicolumn{2}{|c|}{ Grains } & Vmax* $^{*}$ \\
\cline { 2 - 4 } & BRS 267 $^{*}$ & BRS 257 $^{*}$ & $5.63( \pm 0.25)^{\mathrm{a}}$ \\
\hline $\mathbf{P}$ & $6.09( \pm 0.48)^{\mathrm{a}}$ & $5.69( \pm 0.54)^{\mathrm{a}}$ & $18.80( \pm 0.28)^{\mathrm{a}}$ \\
\hline $\mathbf{K}$ & $19.85( \pm 1.62)^{\mathrm{a}}$ & $20.35( \pm 1.20)^{\mathrm{a}}$ & $1.50( \pm 0.14)^{\mathrm{a}}$ \\
\hline $\mathbf{M g}$ & $1.50( \pm 0.00)^{\mathrm{a}}$ & $2.10( \pm 0.14)^{\mathrm{a}}$ & $2.90( \pm 0.00)^{\mathrm{a}}$ \\
\hline $\mathbf{Z n}$ & $2.70( \pm 0.14)^{\mathrm{a}}$ & $3.20( \pm 0.14)^{\mathrm{b}}$ & $0.036( \pm 1.06)^{\mathrm{a}}$ \\
\hline $\mathbf{M n}$ & $0.039( \pm 1.62)^{\mathrm{a}}$ & $0.038( \pm 1.90)^{\mathrm{a}}$ & $0.025( \pm 0.70)^{\mathrm{a}}$ \\
\hline $\mathbf{F e}$ & $0.022( \pm 1.41)^{\mathrm{a}}$ & $0.029( \pm 1.41)^{\mathrm{b}}$ & $0.069( \pm 2.12)^{\mathrm{a}}$ \\
\hline $\mathbf{C u}$ & $0.078( \pm 2.12)^{\mathrm{a}}$ & $0.075( \pm 2.65)^{\mathrm{a}}$ & $0.015( \pm 0.28)^{\mathrm{a}}$ \\
\hline
\end{tabular}

* Means (three replicates), \pm Standard Deviation, followed by the same letters among cultivars indicate no significant differences at $5 \%$ (Tukey Test). 
TABLE III. MINERAL COMPOSITION OF SOYBEAN GRAINS WITH (WT) AND WITHOUT (WIT) TEGUMENT

\begin{tabular}{|c|c|c|}
\hline \multirow{2}{*}{ Minerals $\left(\mathbf{g . K g}^{-1}\right)$} & \multicolumn{2}{|c|}{ Grains } \\
\cline { 2 - 3 } & WT $^{*}$ & WIT $^{*}$ \\
\hline $\mathbf{P}$ & $5.50( \pm 0.22)^{\mathrm{a}}$ & $6.11( \pm 0.31)^{\mathrm{a}}$ \\
\hline $\mathbf{K}$ & $18.90( \pm 0.49)^{\mathrm{a}}$ & $20.4( \pm 1.21)^{\mathrm{a}}$ \\
\hline $\mathbf{C a}$ & $1.76( \pm 0.37)^{\mathrm{a}}$ & $1.63( \pm 0.32)^{\mathrm{a}}$ \\
\hline $\mathbf{M g}$ & $2.86( \pm 0.25)^{\mathrm{a}}$ & $3.00( \pm 0.26)^{\mathrm{a}}$ \\
\hline $\mathbf{Z n}$ & $0.038( \pm 1.41)^{\mathrm{a}}$ & $0.037( \pm 2.86)^{\mathrm{a}}$ \\
\hline $\mathbf{M n}$ & $0.024( \pm 3.51)^{\mathrm{a}}$ & $0.026( \pm 3.51)^{\mathrm{a}}$ \\
\hline $\mathbf{F e}$ & $0.076( \pm 2.58)^{\mathrm{a}}$ & $0.050( \pm 1.19)^{\mathrm{b}}$ \\
\hline $\mathbf{C u}$ & $0.015( \pm 0.15)^{\mathrm{a}}$ & $0.015( \pm 1.05)^{\mathrm{a}}$ \\
\hline
\end{tabular}

*Means (three replicates), \pm Standard Deviation, followed for the same letters between grains (WT) and (WIT) indicate no significant differences at 5\% (Tukey Test).
Ref. [35], comparing the NSI and PDI of cultivars for human consumption without heat processing, reported that BRS 257 presented PDI of $50.07 \%$ and NSI of $78.04 \%$, and BRS 267 cultivar presented $75.71 \%$ of PDI and $74.25 \%$ of NSI. These values are close to those found in this work. The authors emphasize that, since these cultivars present PDI higher than $70 \%$, they could be used for meat products, sauces and soups.

The heat treatment significantly reduced the PDI and the NSI of the grains of BRS 267 and Vmax cultivars (Table IV). It was observed that grains WIT submitted to heat treatment (HT) showed greater reduction of these indexes. This tendency was similar for both cultivars that presented $28.55 \%$ of PDI of and $17.81 \%$ of NSI.

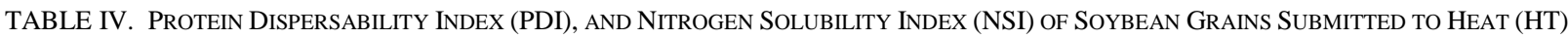
AND NON HEAT (NHT) TREATMENTS

\begin{tabular}{|c|c|c|c|c|c|c|}
\hline \multirow{2}{*}{$\begin{array}{c}\text { Analyses } \\
(\%)\end{array}$} & & \multicolumn{5}{|c|}{ Cultivars } \\
\cline { 3 - 7 } & & BRS 267 NHT $^{*}$ & BRS 267 HT $^{*}$ & Vmax NHT $^{*}$ & Vmax HT $^{*}$ & BRS 257 NHT $^{*}$ \\
\hline \multirow{2}{*}{ PDI } & WT & $80.36( \pm 1.11)^{\mathrm{aA}}$ & $46.62( \pm 1.76)^{\mathrm{bA}}$ & $84.71( \pm 1.90)^{\mathrm{aA}}$ & $41.99( \pm 2.75)^{\mathrm{bA}}$ & $82.58( \pm 3.59)^{\mathrm{aA}}$ \\
\cline { 2 - 7 } & WIT & $88,71( \pm 0.42)^{\mathrm{aB}}$ & $28.76( \pm 1.08)^{\mathrm{bB}}$ & $89.3( \pm 1.90)^{\mathrm{aB}}$ & $28.34( \pm 1.07)^{\mathrm{bB}}$ & $84.35( \pm 5.24)^{\mathrm{aA}}$ \\
\hline \multirow{2}{*}{ NSI } & WT & $6358( \pm 0.51)^{\mathrm{bA}}$ & $27.81( \pm 1.93)^{\mathrm{cA}}$ & $60.06( \pm 0.37)^{\mathrm{aA}}$ & $25.17( \pm 1.97)^{\mathrm{cA}}$ & $62.30( \pm 0.67)^{\mathrm{bA}}$ \\
\cline { 2 - 7 } & WIT & $63.36( \pm 0.76)^{\mathrm{bA}}$ & $15.93( \pm 0.82)^{\mathrm{cB}}$ & $68.01( \pm 0.34)^{\mathrm{aB}}$ & $19.70( \pm 3.61)^{\mathrm{cA}}$ & $60.85( \pm 2.12)^{\mathrm{bA}}$ \\
\hline
\end{tabular}

*Means (three replicates), \pm Standard Deviation, same small/capital letters in the lines/columns indicate no significant differences at 5\% (Tukey test). Where: HT = heat treatment; NHT = non heat treatment; WT = with tegument; WIT = without tegument.

Similar results were found in Ref. [36], that studied the effect of heat treatment $\left(95{ }^{\circ} \mathrm{C}\right.$ for $\left.15 \mathrm{~min}\right)$ in soymilk and observed a reduction of NSI from $90.57 \%$ to $25.31 \%$, because of protein denaturation.

In general, the protein solubility decreased due to denaturation of soybean proteins. Normally, the protein solubility increase with temperature from $0^{\circ} \mathrm{C}$ to $40^{\circ} \mathrm{C}$. The majority of protein tends to denature in temperatures higher than this, causing losses in protein solubility. The thermal denaturation could change the protein solubility, due the increase of the hydrophobic groups in its surface [37].

The NSI and PDI are used as a practical measure to determine functionality of the protein. Soybean cultivars that present high values of NSI and PDI are recommended for develop different soy food products [38]. However, products with low values of NSI and PDI can still be functional, because of good water and lipid absorption, which are the properties necessary for the stability of the meat products [39].

In relation to the content of the isoflavones (Table V) the highest values were observed in grains WT. Studies performer by Ref. [40], utilizing grains by manual dehulled, which not allowed contamination with other parts of the grain, thus is observed that the soybean tegument not present isoflavones. However, in this work, grains were mechanically dehulled and because of that could occur possible losses of the hypocotyls and cotyledons, reducing the content of these compounds in samples WIT (Table V). Those parts of the grains, mainly the hypocotyls presented the higher content of isoflavones, as reported in Ref. [41].

Isoflavones are composed of the aglycone forms (genistein, glycitein and daidzein), which do not have the glucose molecule linked to the main chain; the glucosidic forms (daidzin, glycitin and genistin), which have the linked glucose molecule; and its derivatives malonyl and acetyl forms [42]. The isoflavones are more easily absorbed as aglycones forms, which are readily bioavailable. The glucosidic forms are intact absorbed, and because of that need an initial hydrolyze of the sugar, to be transported by the peripheral circulation. This means that glucosidics will be converted to the aglycone forms (daidzein and genistein) which are the biological active forms [43].

The isoflavone content was significant different for all cultivars, which is due to genetic variability as already observed [44]. Vmax cultivar NHT (WT), presented the highest total content $\left(157.72 \mathrm{mg} .100 \mathrm{~g}^{-1}\right.$ of deffated sample) of glucosidic forms, and BRS 267 NHT (WT) showed the smallest content $\left(68.64 \mathrm{mg} .100 \mathrm{~g}^{-1}\right)$.

After the heat treatment (HT), cultivars showed a reduction in content of glucosidic and malonyl forms (Table V). Studies have showed that depending on the type of soybean processing, occur changes in the profiles of glucosidic and molonyl isoflavones [14]-[46].

Total aglycones (Table V), increased when grains were submitted to heat treatment (HT). This was 3.51 times for BRS 267 cultivar (HT WT) and 2.34 times for Vmax cultivar (HT WT). Ref. [14], [47] also reported, increasing content of isoflavone aglycones, after heat and milling process, which was explained by the cleavage of the glucosidics and malonyl forms in aglycones [48].

Isoflavone content in soybean grains is affected by the genetic variability and environmental conditions. It has been observed that local average temperatures, during seed filling is determinant on formation of the isoflavones (Ref. [49], [50]). The total isoflavone content was 
reduced from $13.14 \%$ for BRS 267 to $7.17 \%$ for Vmax, in heat-treated (HT) grains (Table V). This was also observed by [5]-[14]. In general, isoflavones are not destroyed by heat, but are intra converted to different forms. Isoflavone losses can occur during cooking processing by leaching in the water cooking [46]-[51].

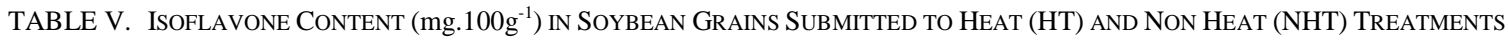

\begin{tabular}{|c|c|c|c|c|c|c|}
\hline \multirow{2}{*}{$\begin{array}{l}\text { Isoflavones } \\
\left(\mathrm{mg} \mathbf{1 0 0 g}^{-1}\right)\end{array}$} & & \multicolumn{5}{|c|}{ Cultivars } \\
\hline & & BRS 267 NHT & BRS 267 HT & Vmax NHT & Vmax HT & BRS 257 NHT \\
\hline \multirow{2}{*}{ Glucosidics } & WT & $68.64( \pm 0.43)^{\mathrm{bA}}$ & $52.48( \pm 0.54)^{\mathrm{dA}}$ & $157.72( \pm 0.0)^{\mathrm{cA}}$ & $142.81( \pm 1.19)^{\mathrm{dA}}$ & $90.81( \pm 0.81)^{\mathrm{aA}}$ \\
\hline & WIT & $50.74( \pm 0.12)^{\mathrm{dB}}$ & $42.96( \pm 0.59)^{\mathrm{cB}}$ & $138.39( \pm 0.18)^{\mathrm{aB}}$ & $119.64( \pm 1.20)^{\mathrm{bB}}$ & $49.68( \pm 2.84)^{\mathrm{dB}}$ \\
\hline \multirow{2}{*}{$\begin{array}{l}\text { Malonyl- } \\
\text { glucosidics }\end{array}$} & WT & $257.02( \pm 0.65)^{\mathrm{bA}}$ & $208.92( \pm 1.44)^{\mathrm{dA}}$ & $580.01( \pm 0.24)^{\mathrm{cA}}$ & $508.76( \pm 3.34)^{\mathrm{eA}}$ & $372.94( \pm 0.38)^{\mathrm{aA}}$ \\
\hline & WIT & $204.77( \pm 0.02)^{\mathrm{bB}}$ & $151.58( \pm 0.65)^{\mathrm{bB}}$ & $544.01( \pm 0.98)^{\mathrm{cB}}$ & $420.58( \pm 2.39)^{\mathrm{aB}}$ & $220.89( \pm 5.52)^{\mathrm{eB}}$ \\
\hline \multirow{2}{*}{ Aglycones } & WT & $8.22( \pm 0.05)^{\mathrm{dA}}$ & $28.86( \pm 0.05)^{\mathrm{bA}}$ & $23.5( \pm 0.25)^{\mathrm{cA}}$ & $55.06( \pm 0.87)^{\mathrm{aA}}$ & $6.67( \pm 0.00)^{\mathrm{dA}}$ \\
\hline & WIT & $7.01( \pm 0.06)^{\mathrm{cB}}$ & $12.72( \pm 0.03)^{\mathrm{bB}}$ & $11.91( \pm 0.03)^{\mathrm{bB}}$ & $39.26( \pm 0.72)^{\mathrm{aB}}$ & $4.39( \pm 0.14)^{\mathrm{dB}}$ \\
\hline \multirow{2}{*}{ TOTAL } & WT & $333.88( \pm 1.04)^{\mathrm{dA}}$ & $290.24( \pm 2.08)^{b A}$ & $761.23( \pm 0.48)^{\mathrm{cA}}$ & $706.62( \pm 5.40)^{\text {aA }}$ & $470.41( \pm 0.05)^{\mathrm{eA}}$ \\
\hline & WIT & $262.52( \pm 0.03)^{\mathrm{dB}}$ & $207.29( \pm 1.21)^{\mathrm{cB}}$ & $694.33( \pm 0.77)^{\mathrm{aB}}$ & $579.50( \pm 4.36)^{\mathrm{bB}}$ & $274.96( \pm 8.50)^{\mathrm{dB}}$ \\
\hline
\end{tabular}

*Means (three replicates), \pm Standard Deviation, same small/capital letters in the lines/columns indicate no significant differences at $5 \%$ (Tukey test) Where: HT = heat treatment; NHT = non heat treatment; WT = with tegument; WIT = without tegument.

In Table VI are presented results of the Kunitz trypsin inhibitor in soybean grains (WT and WIT) submitted to heat treatment. About $80 \%$ of the trypsin inhibitor activity in soybean grains is reduced by heat treatment. This anti nutritional factor acts in the intestinal gastric tract reducing availability of the amino acids, lowering nutritional value of this legume (Ref. [12]-[52]).

Comparing grains of the BRS 267 cultivar (WT and NHT), it is observed lower content (16.57 mg IT. $\mathrm{g}^{-1}$ ) than those for BRS 257 and Vmax cultivars $\left(20.50 \mathrm{mg} \mathrm{IT.g}^{-1}\right.$ and $19.13 \mathrm{mg} \mathrm{IT.} \mathrm{g}^{-1}$, respectively). These results are similar to the observations of Ref. [53], where trypsin inhibitor in different soybean cultivars, sowed in Londrina and Ponta Grossa (Paraná State, Brazil), presented in average $18.04 \mathrm{mg} \mathrm{IT.g^{-1 }}$ and $15.76 \mathrm{mg} \mathrm{IT.g}{ }^{-1}$ for BRS 257 and BRS 267, respectively. Other similar results were also found by Ref. [54].

Comparing data of the cultivars (WT and WIT), nonheat treated, it is observed that when the tegument was taken out, there was a significant increase in the trypsin inhibitor content (Table VI). According to Ref. [28], this is because the trypsin inhibitors are located in the cotyledons of the soybean grains. Therefore, grains WIT can present more concentration of this compound.

The heat treatment in soybean grains promoted a significant reduction of the trypsin inhibitor. BRS 267 cultivar (WT and WIT), presented a reduction of $48.34 \%$ and $73.63 \%$, respectively (Table VI). For Vmax the reduction was of $58.70 \%$ and $70.86 \%$ for grains WT and WIT, respectively. The higher reduction in grains WIT, can be explained by the increasing of the superficial area of the grain after dehulled. This may expose greater area to heat treatment process, improving inactivation of the trypsin inhibitor. According to Ref. [55], thermal inactivation of the inhibitor is variable and depends on different factors, such as temperature, time and type of heat, size of the particles, humidity, and chemical structure of the inhibitor.

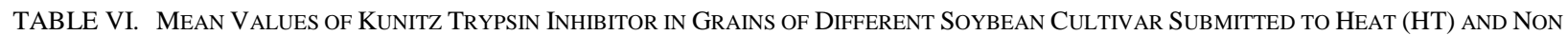
HEAT (NHT) TREATMENT

\begin{tabular}{|c|c|c|c|c|c|c|}
\hline \multirow{2}{*}{$\begin{array}{c}\text { Analysis } \\
(\text { mg IT.g }\end{array}$} & & \multicolumn{5}{|c|}{ Cultivars } \\
\cline { 3 - 8 } & & BRS 267 NHT $^{*}$ & BRS 267 HT $^{*}$ & Vmax NHT $^{*}$ & Vmax HT $^{*}$ & BRS 257 NHT* $^{*}$ \\
\hline \multirow{2}{*}{ Kunitz trypsin inhibitor activity } & WT & $16.57( \pm 0.67)^{\mathrm{bA}}$ & $8.56( \pm 0.91)^{\mathrm{cA}}$ & $19.13( \pm 0.38)^{\mathrm{aA}}$ & $7.90( \pm 1.25)^{\mathrm{cA}}$ & $20.50( \pm 0.16)^{\mathrm{aA}}$ \\
\cline { 2 - 8 } & WIT & $20.18( \pm 0.13)^{\mathrm{bB}}$ & $5.32( \pm 0.60)^{\mathrm{CB}}$ & $23.96( \pm 0.46)^{\mathrm{aB}}$ & $6.98( \pm 0.69)^{\mathrm{dA}}$ & $23.66( \pm 0.21)^{\mathrm{aB}}$ \\
\hline
\end{tabular}

*Means (three replicates), \pm Standard Deviation, same small/capital letters in the lines/columns indicate no significant differences at $5 \%$ (Tukey test). Where: $\mathrm{HT}=$ heat treatment; NHT = non heat treatment; WT = with tegument; WIT = without tegument.

\section{A. Isoenzyme Lipoxygenases (LOX)}

The heat treatment process at $98^{\circ} \mathrm{C}$ for 5 min was efficient to eliminate the lipoxygenases present in BRS 267 and Vmax cultivars, as it can be observed in Fig. 1. In the first row in the Fig. 1, are the standard color for each cultivar NHT. BRS 257 cultivar do not present the three isoenzyme (lipoxygenases - LOX1, LOX2 and LOX3) and presented the green color. Vmax and BRS 267 are cultivars that present the isoenzyme lipoxygenases and present the yellow color). At the second and the third rows, are BRS 267 and Vmax cultivars that were HT, since all are green color this showed the efficiency of heat treatment for inactivation of the enzymes.

Ref. [5], also verified inactivation of the lipoxygenase activity after cooking process at $121^{\circ} \mathrm{C}$ for $5 \mathrm{~min}$. Ref. [56], reported that heat treatment for $90 \mathrm{~s}$ before cooking was effective to inactivate $99 \%$ of the lipoxygenase activiy. In studies performed by Ref. [57], the authors verifiyed that in temperatures higher than $91^{\circ} \mathrm{C}, 99 \%$ of the LOX can be inactivated. Ref. [58], sugested that inactivation of the LOX throughout thermal treatment improves flavor of the soybean grains, mainly beany flavor which is originated in association of carbonilic compounds of long chain with protein fraction, catalized 
by the enzymes LOX, that correspond to $1 \%$ of the total protein present in the grains [52].

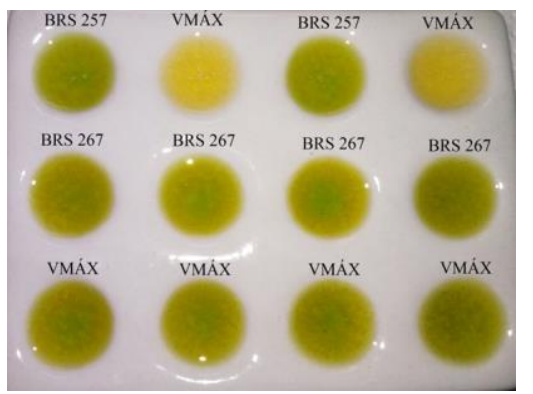

Figure 1. Colorimetric test to determine presence and absence of the isoenzyme lipoxygenases (LOX) in grains of the cultivar BRS 257, BRS 267 and Vmax. (First row - green color (abscence of the LOX1, LOX2 and LOX3) in BRS 257 NHT; yellow color (presence of the lipoxygenases) in Vmax (NHT); In the second and third rows: cultivars BRS 267 and Vmax (HT) with inactivated enzymes (green color).(NHT $=$ non heat treatment; $\mathrm{HT}=$ heat treatment)

\section{CONCLUSION}

The studied physical chemical composition of the soybean grains were different among the cultivars. BRS 267 showed higher protein content than other cultivars, which is important factor to improve nutritional value. This cultivar, however, presented lower level of total isoflavones. Vmax cultivar presented the highest content of lipids, and should be utilized to process oily products for food and non food uses. This cultivar also presented the highest content of total isoflavones. BRS 257 showed an intermediate chemical composition, when comparing with other cultivars. Therefore this cultivar has the advantage of not need thermal inactivation of the LOXs.

Mineral composition was similar in all cultivars, where the $\mathrm{K}$ was the mineral in highest amount. Grains WT presented an amount of Fe superior to the grains WIT.

The heat treatment process promoted changes in the soybean grains, mainly by reducing protein solubility, due to protein denaturation. In grains WIT, protein denaturation was greater than in grains WT. Thermal treatment also promoted reduction of the glucosidic and malonyl isoflavones, but increased aglycones forms in all cultivars. Heat treatment was efficient to decrease about $70 \%$ of Kunitz trypsin inhibitor for grains WIT. It was also effective on inactivation of lipoxygenases (LOX) for BRS 267 and Vmax. Therefore, the heat treatment, although decreasing protein solubility, it is necessary for conventional soybeans, to improve flavor and to reduce anti nutritional factors. Null lipoxygenase cultivars, that do not need a drastic heat treatment, are important to process food products with better protein quality and improved flavor. Depending on the objective of soybean utilization, different cultivars and treatments should be applied. Genetic breeding to obtain soybean cultivars with special characters is important to process high quality soybean products.

\section{ACKNOWLEDGMENT}

The authors are grateful to CAPES, Embrapa Soybean, Embrapa Wheat, Universidade Regional Alto Uruguai
URI-Erechim, National Brazilian Research Council (CNPq), and Adilson de Oliveira Jr., Rodrigo Santos Leite and Marcos Contijo Mandarino for the analysis of the minerals and isoflavones.

\section{REFERENCES}

[1] P. Chen and G. R. Buss, "Breeding soybean for the soyfoods market: Specific traits and strategies for selection," in Proc. III World Soybean Research Conf., IV International Soybean Processing and Utilization Conf. and III Congresso Brasileiro de Soja, Foz do Iguaçu, 2004, pp. 830-835.

[2] M. C. Carrão-Panizzi, P. F. Bertagnolli, M. L. Strieder, L. M. Costamilan, and J. U. V. Moreira, "Soybean breeding for food at embrapa wheat - agricultural crop 2011/2012," Embrapa Trigo. pp. 27-31, 2012.

[3] M. C. Carrão-Panizzi, "Breeding for obtaining more suitable soybean cultivars for human consumption," Journal of Clinical Nutrition, vol. 15, pp. 330-340, 2001.

[4] M. C. Carrão-Panizzi, A. Pipolo, J. M. G. Mandarino, N. E. Arantes, et al., "Breeding specialty soybean cultivars for processing and value-added utilization at Embrapa in Brazil," in Proc. World Soybean Research Conf., Beijing, 2009, pp. 113.

[5] J. B. Silva, "Characteristics of conventional soybean cultivars and for human consumption: physical, chemical and sensory analysis (human senses and electronic sensors)," Ph.D. thesis, Dept. Food Sci., Univ. Londrina, Brazil, 2009.

[6] M. C. Carrão-Panizzi and J. B. Silva, "Soy in food: Quality in grain production with added value," in Proc. Congreso De La Soja Del Mercosur - Mercosoja, Rosário, 2011, pp. 1-3.

[7] M. M. H. Villalva, "Chemical modification to obtain an isolated soy protein with solubility similar to that of human casein," M.S. dissertation, Dept. Sci. Food Technol. Federal Univ. Viçosa, Brazil, 2008.

[8] L. K. Mcklem, "Investigation of molecular forces involved in gelation of commercially prepared soy protein isolates," M.S. dissertation, Faculty of North Carolina State Univ., North Caroline, USA, 2002.

[9] O. R. Fennema, K. L. Parkin, and S. Damodaran, Química de Alimentos de Fennema, $4^{\text {st }}$ ed., São Paulo, Brazil: Editora Artmed, 2010.

[10] F. Brouns, "Soya isoflavones: A new and promising ingredient for the health foods sector," Food Research International, vol. 35, pp. 187-193, 2002.

[11] L. R. Cardoso, M. G. A. Oliveira, F. Q. Mendes, et al., "Protease activity inhibitors in soybeans genetically improved strains," Nutrition, vol. 18, no. 1, pp. 19-26, 2007.

[12] M. F. S. S. Brune, M. O. Pinto, M. C. G. Peluzio, M. A. Moreira, and E. G. BARROS, "Biochemical and nutritional evaluation of a free soybean line Kunitz trypsin inhibitor and lectins," Food Science and Technology, vol. 30, no. 3, pp. 657-663, 2010.

[13] A. V. Konareva, I. N. Anisimovab, et al., "Serine proteinase inhibitors in the compositae: distribution, polymorphism and properties," Phytochemistry, vol. 59, pp. 279-291, 2002.

[14] S. Ciabotti, M. F. P. Barcellos, J. M. G. Mandarino, and A. G. Tarone, "Chemical and biochemical evaluation of grains, soymilk and tofu to normal soybean and soybean lipoxygenase-free," Agrotechnical Science, vol. 30, no. 5, pp. 920 - 929, 2006.

[15] J. B. França Neto, F. C. Krzyzanowski, G. P. Pádua, N. P. Costa, and A. A. Henning, "High quality soybean seed production technology - Serial Seeds," Circular Técnica, no. 40, Mar. 2007.

[16] M. C. Carrão-Panizzi, "Breeding for obtaining more suitable soybean cultivars for human consumption," Journal of Clinical Nutrition, vol. 15, pp. 330-340, 2001.

[17] AOAC (Association of Official Analytical Chemists), Official Methods of Analysis, $18^{\text {th }}$ ed., Washington: AOAC, 2007, pp. 3000.

[18] F. C. Silva, "Chemical analysis of plant tissue," in Chemical Analysis Manual of Soil, Plant and Fertilizer, 2 Ed., Brasília: Embrapa Informação Tecnológica, 2009, pp. 193-304.

[19] M. F. Giné-Rosias, "Atomic emission spectrometry with inductively coupled plasma (ICP-AES)," CENA, Piracicaba, pp. $148,1998$.

[20] American Oil Chemists' Society, Official and Tentative Methods of the American Oil Chemists Society - Official Method Ba 11-65, $3^{\text {th }}$ ed., Champaign: AOCS Press, 1969. 
[21] American Oil Chemists' Society, Official and Tentative Methods of the American Oil Chemists Society - Official Method Ba 10-65, $3^{\text {th }}$ ed., Champaign: AOCS Press, 1980.

[22] M. A. Berhow, "Modern analytical techniques for flavonoid determination," in Flavonoids in the Living Cell, B. S. Buslig and J. A. Manthey, Ed., New York: Klusher Academic, 2002, pp. 6176.

[23] M. C. Carrão-Panizzi, S. P. G. Favoni, and A. Kikuchi, "Extraction time for isoflavone determination," Brazilian Archives of Biology and Technology, vol. 45, no. 4, pp. 515-518, Dec. 2002.

[24] M. L. Kakade, J. J. Rackis, J. E. Mcghee, and G. Puski, "Determination of trypsin inhibitor activity of soy products: A collaborative analysis of an improved procedure," Cereal Chemistry, vol. 51, pp. 376-383, 1974

[25] I. Suda, M. Hajika, Y. Nishiba, E. Furuta, and K. Igita, "Simple and rapid method for the selective detection of individual lipoxygenase isozymes in soybean seeds," Journal of Agricultural and Food Chemistry, vol. 43, pp. 742-747, 1995.

[26] B. Axelrod, T. M. Cheesbrough, and S. Laasko, "Lipoxygenases from soybeans," Methods Enzymol, vol. 71, pp. 441-451, 1981.

[27] A. P. C. Martinez, P. C. C. Martinez, M. C. Souza, and S. G. Canniatti Brazaca, "Chemical changes in soybean grain germination," Food Science and Technology, vol. 31, no. 1, pp. 23-30, 2011.

[28] R. Bressani, "Grains quality of common beans," Reviews International, vol. 9, pp. 237-297, 1993.

[29] J. E. P. Saidu, "Development, evaluation and characterization of protein, isoflavone enriched soymilk," Ph.D. thesis, Faculty of the Louisiana State Univ., Louisiana, 2005.

[30] L. Ramírez-Cárdenas, A. J. Leonel, and N. M. B. Costa, "Effect of domestic processing on the nutrient content and anti-nutritional factors of different cultivars of common bean," Food Science and Technology, vol. 28, no. 1, pp. 200-213, Jan.-Mar. 2008.

[31] V. T. Benassi and S. H. Prudencio, "Soybean processing impacts the retention minerals, proteins and isoflavones tofu," Brazilian Journal of Food Nutrition, vol. 24, no. 1, pp. 51-59, Jan.-Mar. 2013.

[32] C. R. Vieira, L. C. Cabral, and A. C. O. Paula, "Proximate composition and amino acid content, fatty acids and minerals of six soybean cultivars intended for human consumption," Pesquisa Agropecuária Brasileira, vol. 34, no. 7, pp. 1277-1283, 1999.

[33] M. Rosset, "Distribution minerals and phytic acid in the soluble extract and tofu soybean processing," M.S. dissertation, Dept. Food Sci. Londrina Univ., Londrina, Brazil, 2007.

[34] A. W. Carvalho, "Bioavailability of iron and protein quality of soybean cultivar UFVTN 105AP with high protein content," M.S. dissertation, Dept. Nutr. Sci., Viçosa Federal Univ., Viçosa, Brazil, 2009.

[35] S. O. Silva, E. F. Oliveira, G. B. A. Oliveira, J. B. Silva, et al., "Chemical composition and solubility of special soybean cultivars protein for human consumption in the processing of soluble soy extract," Embrapa Soja. Documents, vol. 297, pp. 134-139, 2008.

[36] J. L. S. Lemos, M. C. Mello, and L. C. Cabral, "Study of the solubility of the soluble protein extracts from soybean powder," Food Science and Technology, vol. 17, no. 3, pp. 337-340, 1997.

[37] J. A. Ordóñez, M. I. C. Rodríguez, L. F. Álvarez, M. L. G. Sanz, G. D. G. F. Minguillón, L. H. Perales, and M. D. S. Cortecero, "Food technology: Component food and processes," Porto Alegre, Editora Artmed, pp. 294, 2005.

[38] J. H. V. de Kamer and L. V. Ginkel, "Rapid determination of crude fiber in cereals," Cereal Chemistry, vol. 29, no. 4, pp. 239251, Jul.-Aug. 1952.

[39] A. Visser and A. Thomas, "Review: Soya protein products - Their processing, functionality, and application aspects," Food Reviews International, vol. 3, no. 1-2, pp. 1-32, Jan.-Feb. 1987.

[40] S. Kudou, Y. Fleury, D. Welti, D. Magnolato, T. Uchida, K. Kitamura, and K. Okubo, "Malonyl isoflavone glycosides in soybean seeds (Glycine max Merrill)," Agricultural and Biological Chemistry, vol. 55, no. 9, pp. 2227-2233, 1991.

[41] C. E. Silva, M. C. Carrão-Panizzi, J. M. G. Mandarino, R. S. Leite, and A. P. A. Mônaco, "Levels of isoflavones in whole grains and components of grains of different soybean cultivars (Glycine max (L.) Merrill)," Brazilian Journal of Food Technology, vol. 15, no. 2, pp. 150-156, Apr.-Jun. 2012.
[42] M. C. Carrão-Panizzi, "Evaluation of soybean cultivars for the levels of isoflavones," Pesquisa Agropecuária Brasileira, vol. 31, no. 10 , pp. 691-698, 1996

[43] K. D. R. Setchell, N. M. Brown, P. Desai, L. Zimmer-Nechemias, B. E. Wolfe, et al., "Bioavailability of pure isoflavones in healthy humans and analysis of commercial soy isoflavone supplements," Journal of Nutrition, vol. 131, pp. 1362S-1375S, 2001.

[44] M. C. Carrão-Panizzi, M. Berhow, J. M. G. Mandarino, and M. C. N. Oliveira, "Environmental and genetic variation of isoflavone content of soybean seeds grown in Brazil," Brazilian Agropecuary Journal, vol. 44, no. 11, pp. 1444-1451, 2009.

[45] L. Coward, M. Smith, M. Kirk, and S. Barnes, "Chemical modification of isoflavones in soyfoods during cooking and processing," American Journal of Clinical Nutrition, vol. 68, no. 6 , pp. 1486S-1491S, 1998.

[46] C. Jackson, J. P. Dini, H. P. V. Rupasinghe, H. Faulkner, V. Poysa, D. Buzzell, and S. Degrandis, "Effects of processing on the content and composition of isoflavones during manufacturing of soy beverage and tofu," Process Biochemistry, vol. 37, no. 10, pp. 1117-1123, May 2002.

[47] M. P. Ferreira, M. C. N. Oliveira, J. M. G. Mandarino, J. B. Silva, E. I. Ida, and M. C. Carrão-Panizzi, "Changes in the isoflavone profile and in the chemical composition of tempeh during processing and refrigeration," Brazilian Agropecuary Journal, vol. 46, no. 11, pp. 1555-1561, Nov. 2011.

[48] S. Ciabotti, "Chemical, physical, chemical and sensory aspects of soymilk and tofu obtained from conventional soybean cultivars and lipoxygenase-free," M.S. dissertation, Dept. Food Sci., Lavras Federal Univ., Lavras, Brazil, 2004

[49] C. Tsukamoto, S. Shimada, K. Igita, S. Kudou, M. Kokubun, and K. Okubo, "Factors affecting isoflavone content in soybean seeds: changes in isoflavones, saponins, and composition of fatty acids at different temperatures during seed development," Journal of Agricultural and Food Chemistry, vol. 43, pp. 1184-1192, 1995.

[50] M. C. Carrão-Panizzi, A. S. Simão, and A. Kikuchi, "Effects of genotypes, environment and hydrothermal treatments at a concentration of aglucone isoflavones in soybeans," Brazilian Agropecuary Journal, vol. 38, no. 8, pp. 897-902, 2003.

[51] M. Uzzan and T. P. Labuza, "Critical issues in R\&D of soy isoflavones-enriched foods and dietary supplements," Journal of Food Science, vol. 69, no. 3, pp. 77-86, 2004.

[52] M. R. P. Monteiro, N. M. B. Costa, M. G. A. Oliveira, C. V. Pires, and M. A. Moreira, "The protein quality of soybean lines with absence of kunitz trypsin inhibitor and lipoxygenase isozymes," Nutrition Journal, vol. 17, no. 2, pp. 195-205, 2004.

[53] O. F. Galão, M. C. Carrão-Panizzi, J. M. G. Mandarino, R. S. Leite, T. Claus, and J. V. Visentainer, "Kunitz trypsin Inhibitor and phytic acid levels in conventional and genetically modified soybean seeds from Londrina and Ponta Grossa, South Brazil," Acta Scientiarum. Technology, vol. 36, no. 4, pp. 727-731, 2014.

[54] E. F. Oliveira, S. O. Silva, J. B. Silva, G. B. A. Oliveira, P. J. Campos-Filho, et al., "Determination of isoflavones and trypsin inhibitor kunitz in grain and soybean extracts soluble fe obtained cultivars special for food," Embrapa Soja. Documents, vol. 297, pp. 128-133, 2008.

[55] M. R. B. Carvalho, P. G. Kirschnik, K. C. Paiva, and F. S. Aiura, "Evaluation of the activity of trypsin inhibitors after enzymatic digestion thermally treated soybean," Nutrition Journal, vol. 15 , no. 3, pp. 67-272, 2002.

[56] L. A. Mozzoni, R. O. Morawicki, and P. Chen, "Canning of vegetable soybean: Procedures and quality evaluations," International Journal of Food Science and Technology, vol. 44, no. 6, pp. 1125-1130, 2009.

[57] B. D. Brown, "Minimizing protein insolubilization during thermal inactivation of lipoxygenase in soybean cotyledons," Journal of the American Oil Chemist's Society, vol. 59, no. 2, pp. 88-92, 1982.

[58] M. A. Felix, S. G. Canniatti Brazaca, and F. M. V. F. Machado, "Sensory analysis of soybean (Glycine max (L.) Merrill) roasted by different treatments," Food Science and Technology, vol. 31, no. 1 , pp. 56-64, 2011 . 